\title{
Sapi-Sapian, Contextualizing Mathematical Concepts Through Cultural Tradition
}

\author{
Widyasari $^{*}$, Rachmaniah Mirza Hariastuti ${ }^{2}$ \\ ${ }^{1,2}$ Universitas PGRI Banyuwangi \\ *mirzarachmaniah@gmail.com
}

Received: November 2020; Accepted: December 2020; Published: January 2021

\begin{abstract}
Sapi-sapian is one of the traditions in Kenjo Village which is carried out every Muharram month as an expression of gratitude to God for an abundance of agricultural crops. Sapi-sapian tradition contains four processions, namely the selametan pecel gerang, tumpeng serakat, ider bumi oncoroncoran, and the celebration, which contain ethnomathematics. In order to get the most out of ethnomathematics in the Sapi-sapian tradition, a qualitative-descriptive study was conducted as a method. Due to the conditions of the Covid-19 pandemic which caused the Sapi-sapian tradition to be carried out optimally in 2020, data were collected using in-depth interviews, and cultural documentation. The research informants were the Chief of the Kenjo Village Custom, the Deputy Head of the Adat, and one resident who had been involved in the implementation of the Sapi-sapian tradition. The data obtained were analyzed qualitatively based on several analysis processes in ethnographic research. The results showed that there are mathematical concepts found in the Sapisapian tradition of Kenjo Village, including: two and three dimensional geometry, fractions, transformations, and traditional measurements with non-standard units.
\end{abstract}

Keywords: sapi-sapian, cultural tradition, ethnomathematics.

How to Cite: Widyasari \& Hariastuti, R. M. (2021). Sapi-Sapian, Contextualizing Mathematical Concepts Through Cultural Tradition. Journal of Medives: Journal of Mathematics Education IKIP Veteran Semarang, 5(1), 36-47. 


\section{PENDAHULUAN}

Tradisi yang dilahirkan manusia disebut adat istiadat, yaitu kebiasaan yang bersifat supranatural meliputi nilainilai budaya, norma-norma, hukum dan aturan yang berkaitan dari hasil turun temurun leluhur atau nenek moyang (Darwis, 2017). Tradisi yang dilakukan masyarakat di berbagai daerah di Indonesia merupakan perwujudan keanekaragaman budaya masyarakat Indonesia. Salah satu daerah di Indonesia yang memiliki keanekaragaman tradisi adalah Banyuwangi. Masyarakat asli Banyuwangi dikenal sebagai suku Using. Salah satu tradisi yang dimiliki masyarakat suku Using berhubungan dengan keselamatan bersama, di antaranya tumpeng sewu, seblang, barong ider bumi, kebo-keboan, sapisapian, dan lain-lain.

Sapi-sapian merupakan tradisi yang dilaksanakan di Desa Kenjo, Kecamatan Glagah, Kabupaten Banyuwangi, dan belum dikenal secara luas. Masyarakat Desa Kenjo masih menjunjung tinggi nilai-nilai budaya dari generasi ke generasi. Sapi-sapian di Desa Kenjo merupakan bagian dari ritual adat sebagai ungkapan syukur atas melimpahnya hasil panen pertanian yang dilakukan pada bulan Muharram setiap tahun.

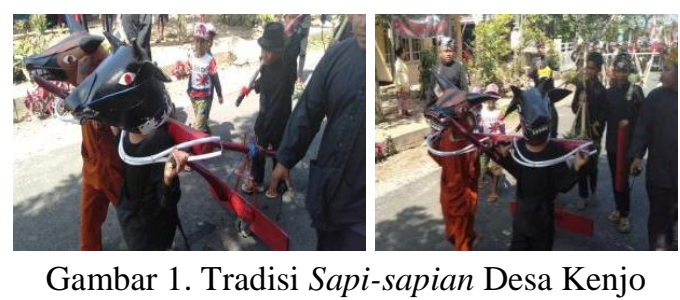

Keunikan dari sapi-sapian Desa Kenjo adalah adanya warga laki-laki yang didandani menyerupai sapi untuk menggantikan peran sapi sesungguhnya. Tradisi ini diawali dengan selametan pecel gerang (gerang adalah sejenis ikan teri yang diawetkan/diasinkan) yang bertujuan untuk mengirim doa kepada leluhurnya yang dilaksanakan di makam mbah Daeng (leluhur masyarakat Kenjo). Selanjutnya dilakukan kegiatan makan bersama oleh warga Desa Kenjo di depan pekarangan rumah warga, dan dikenal sebagai prosesi tumpeng serakat. Kegiatan berikutnya adalah prosesi ider bumi oncor-oncoran serta tradisi arakarakan hasil bumi dan sapi-sapian yang diperankan oleh manusia.

Rangkaian kegiatan tradisi sapisapian secara kasat mata menunjukkan adanya bentuk-bentuk geometris pada peralatan yang digunakan dalam setiap prosesi. Selain itu tampak juga adanya penentuan banyak pelaksana kegiatan yang bersesuaian dengan konsep membilang. Konsep geometris dan membilang merupakan bagian dari konsep-konsep matematika yang dapat diidentifikasi dalam tradisi sapi-sapian.

D’Ambrosio (2001) menyampaikan bahwa etnomatematika berasal dari kata ethnomathematics, yang terbentuk dari kata ethno (mengacu pada kelompok kebudayaan yang dapat dikenali), mathema (penjelasan dan pemahaman akan lingkungan budaya), serta tics (teknik). D'Ambrosio juga menyebut bahwa "the mathematics which is practiced among identifiable cultural groups such as national-tribe societies, labor groups, children of certain age brackets and professional classes", is 
called ethnomathematics (dalam Cimen, 2014). Abi (2016) menyebutkan bahwa etnomatematika merupakan konsep matematika yang termuat dalam budaya dan dilaksanakan oleh sekelompok orang dalam kehidupan sehari-hari.

Etnomatematika dapat dieksplorasi dari berbagai tradisi budaya untuk dijadikan bahan dalam pembelajaran matematika kontekstual. Hal ini didukung oleh pendapat Bishop, bahwa budaya akan mempengaruhi perilaku individu dan memiliki peran yang besar pada perkembangan pemahaman individual, termasuk pembelajaran matematika (Tandililing, 2013). Eksplorasi budaya tersebut dapat dilakukan karena tradisi budaya merupakan bagian yang dekat dengan kehidupan siswa, khususnya yang tinggal dalam kelompok masyarakat pelaksana tradisi budaya tersebut.

Beberapa penelitian telah dilakukan sebelumnya untuk mengeksplorasi etnomatematika dalam berbagai tradisi budaya baik di Banyuwangi maupun di wilayah lain. Penelitian Cahyani, Setiawan, \& Yudianto (2018) memberikan kesimpulan bahwa pada perangkat yang digunakan dalam pelaksanaan upacara adat kebo-keboan di Desa Alasmalang, Kecamatan Singojuruh, Kabupaten Banyuwangi memuat konsep geometri seperti bangun datar, kekongruenan dan kesebangunan. Pada tradisi budaya angklung paglak Banyuwangi dapat diidentifikasi adanya konsep matematika seperti: bentuk geometris dua dan tiga dimensi, satuan pengukuran tradisional, kesamaan ukuran, dan kombinasi (Hidayatulloh \& Hariastuti, 2018). Penelitian Aini, dkk
(2019) memberikan kesimpulan bahwa terdapat konsep matematika seperti bangun datar, kesebangunan, kekongruenan, dan operasi bilangan pada budaya karabhen sape Madura. Tradisi tumpeng sewu Desa Kemiren Banyuwangi memuat aktivitas berhitung, pengukuran serta konsep matematika seperti : aljabar, aritmetika, dan geometri (Himmah, dkk., 2019). Berbagai hasil penelitian yang telah dilakukan menunjukkan bahwa belum pernah dilakukan penelitian etnomatematika terkait tradisi sapi-sapian Desa Kenjo. Hal tersebut menjadi dasar untuk dilakukan eksplorasi tradisi sapi-sapian Desa Kenjo dan identifikasi etnomatematika yang termuat dalam tradisi tersebut.

\section{METODE PENELITIAN}

Penelitian ini menggunakan penelitian kualitatif-deskriptif yang bertujuan untuk mengeksplorasi tradisi budaya Sapi-sapian di Desa Kenjo dan mengidentifikasi etnomatematika dalam tradisi tersebut. Penelitian diawali dengan penentuan informan menggunakan metode purposive sampling. Informan ditentukan sebanyak 3 orang, yaitu: Ketua Adat Desa Kenjo (informan 1), Wakil Ketua Adat Desa Kenjo (informan 2), dan satu warga yang pernah terlibat dalam pelaksanaan tradisi sapi-sapian (informan 3). Informan tersebut dipilih karena dianggap paling tahu tentang tradisi sapi-sapian Desa Kenjo dan secara langsung terlibat dalam budaya tersebut.

Karena kondisi pandemi covid-19 yang terjadi sepanjang proses penelitian dan keputusan dari pelaksana tradisi 
untuk meniadakan beberapa kegiatan, maka pengumpulan data dilakukan dengan metode wawancara mendalam dan dokumentasi budaya dari tahuntahun sebelumnya. Selanjutnya, data dianalisis sesuai dengan analisis dalam pendekatan etnografi. Hasil analisis merupakan tema budaya yang disajikan secara deskriptif.

\section{HASIL DAN PEMBAHASAN \\ Eksplorasi Tradisi Sapi-sapian}

Penelitian ini dilakukan di Desa Kenjo, Kecamatan Glagah, Kabupaten Banyuwangi selama bulan Juli sampai Agustus 2020 dengan pertimbangan bahwa tradisi sapi-sapian hanya dilaksanakan di Desa tersebut. Tradisi sapi-sapian ditahun 2020 tidak dilaksanakan sesuai dengan rangkaian yang seharusnya. Prosesi yang tetap dilaksanakan pada tradisi ini adalah selametan pecel gerang dan tumpeng serakat. Sedangkan prosesi ider bumi oncor-oncoran dan perayaan tidak dilaksanakan sesuai dengan anjuran dari pemerintah untuk tidak melakukan rangkaian kegiatan yang menimbulkan kerumunan warga.

Berdasarkan hasil wawancara dengan ketiga informan dan dokumentasi budaya yang telah dilakukan, dapat diketahui bahwa tradisi ini masih dilakukan secara turun-temurun hingga saat ini, walaupun sebelumnya pernah vakum sekitar tahun 1940-an sampai tahun 2014. Namun informan tidak memiliki informasi yang pasti tentang penyebab kevakuman tradisi tersebut karena generasi sebelumnya tidak menceritakan alasan tersebut. Adapun makna dari tradisi sapi-sapian merupa- kan wujud ungkapan syukur kepada Tuhan Yang Maha Esa atas melimpahnya hasil panen pertanian.

Tradisi sapi-sapian diawali dengan beberapa perlombaan antar warga Desa, seperti lomba nginang (mengunyah kinang yang terdiri dari daun sirih, buah jambe, kapur sirih/enjet, gambir, dan tembakau/seseg yang dipercaya orang terdahulu sebagai penguat gigi), lomba nape (membuat tape berbahan dasar singkong), dan lomba mancing belut (menangkap belut) dengan menggunakan alat yang dinamakan kicer/bubu bambu dan seser atau serokan. Kicer merupakan perangkap ikan yang terbuat dari anyaman bambu dan berbentuk bumbung dengan panjang $\pm 60-80 \mathrm{~cm}$. Cacing diikat pada bagian dalam kicer sebagai umpan. Sedangkan seser adalah alat bantu penangkap ikan yang terbuat dari anyaman bambu dengan panjang $\pm 60-85 \mathrm{~cm}$. Lombalomba tersebut umumnya dilakukan 1 sampai 2 hari sebelum tradisi dilaksanakan dengan tujuan warga Desa Kenjo tetap melestarikan kebiasaan yang dilakukan generasi terdahulu.

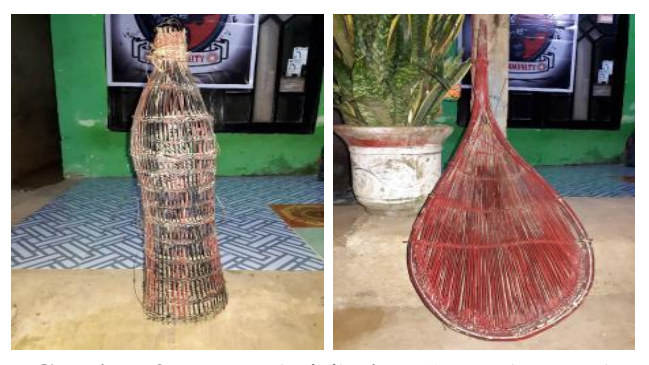

Gambar 2. Kicer (Kiri) dan Seser (Kanan)

Sebelum tradisi sapi-sapian dilaksanakan, warga Desa mempersiapkan berbagai kebutuhan untuk tradisi tersebut. Persiapan tersebut dilakukan dalam bentuk: membuat kepala sapi- 
sapian, menyiapkan berbagai buah dan sayuran, serta keperluan lain yang digunakan dalam tradisi tersebut. Kepala sapi-sapian dibuat oleh warga Desa Kenjo yang memiliki keterampilan khusus membuatnya.

Kepala sapi-sapian dibuat dari karpet berukuran 2 x 1,5 meter. Karpet tersebut dapat menghasilkan 2 kepala sapi-sapian ukuran dewasa atau 3 kepala sapi-sapian ukuran anak-anak. Pembuatan kepala sapi-sapian tersebut dilakukan menggunakan ukuran jari orang dewasa, seperti: penentuan jarak antara tanduk kanan dan tanduk kiri sebesar satu jengkal, jarak antara tanduk dan mata sebesar tiga jari, serta jarak antara tanduk dan telinga sebesar satu ruas jari telunjuk. Jarak antara tanduk kanan dan kiri dilakukan dengan menentukan posisi tengah-tengah kepala sehingga diperoleh jarak yang sama.

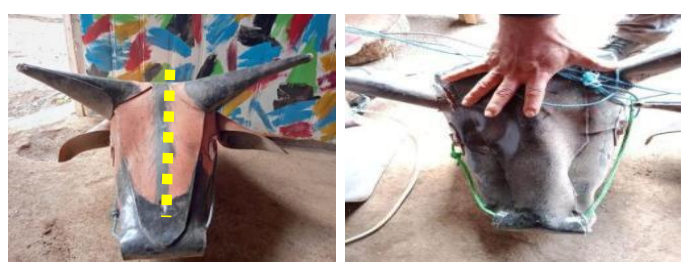

Gambar 3. Posisi Tengah pada

Kepala Sapi-sapian (Kiri) dan Jarak antara Tanduk Kanan dan Tanduk Kiri (Kanan)
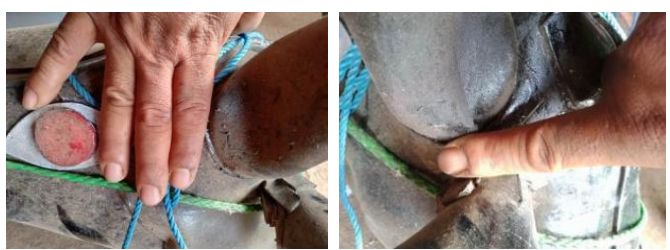

Gambar 4. Jarak antara Tanduk dan Mata (Kiri) dan Jarak antara Tanduk dan Telinga (Kanan)

Jenis kelamin pada sapi-sapian dapat diketahui dari bentuk tanduknya. Sapi jantan memiliki tanduk yang lebih panjang dibanding sapi betina. Di masa sebelum vakum, kepala sapi-sapian ada yang dibuat dari tanduk sapi asli. Untuk saat ini yang tersisa hanya kepala sapisapian yang terbuat dari karpet.
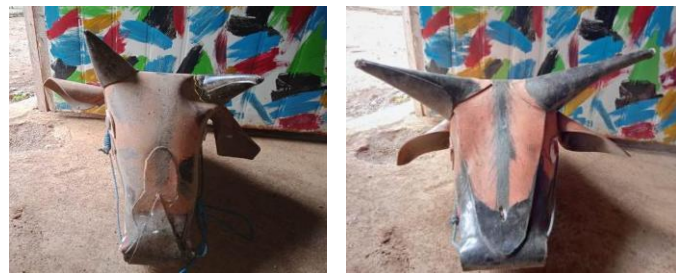

Gambar 5. Kepala Sapi-sapian Betina (Kiri) dan Jantan (Kanan)

Selain proses pembuatan kepala sapi-sapian, juga dilakukan persiapan acara dalam bentuk pengumpulan dan penataan hasil pertanian warga Desa Kenjo seperti buah dan sayur. Buah dan sayuran tersebut nantinya akan dibawa oleh kaum wanita keliling desa dengan menggunakan wadah berbentuk keranjang anyaman bambu yang dinamakan rinjeng dan ireg. Sedangkan kaum lakilaki akan membawa hasil pertanian tersebut dengan alat pikul yang dinamakan cingkek.

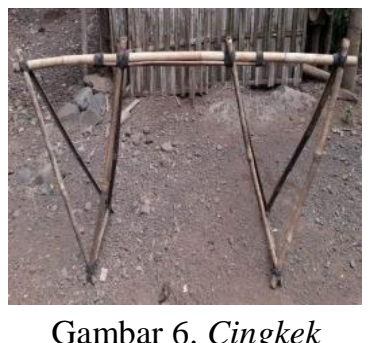

Rinjeng dan ireg merupakan dua wadah yang serupa tetapi berbeda ukuran dan bentuk. Rinjeng memiliki kaki dibagian bawah yang berbentuk lingkaran, sedangkan ireg tidak memiliki kaki dibagian bawah dan ukurannya lebih kecil daripada rinjeng. Rinjeng dan ireg ukuran kecil biasa dibawa oleh 
dayang (putri dalam prosesi perayaan yang diperankan oleh gadis yang tidak sedang menstruasi), sedangkan ireg ukuran besar dibawa oleh wanita dewasa.
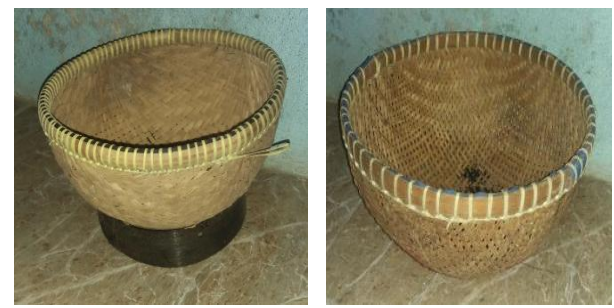

Gambar 7. Rinjeng (Kiri) dan Ireg (Kanan)

Tradisi sapi-sapian Desa Kenjo memuat empat prosesi, yaitu: selametan pecel gerang, tumpeng serakat, ider bumi oncor-oncoran, dan perayaan. Prosesi selametan pecel gerang menjadi pembuka yang menunjukkan akan dilaksanakan tradisi sapi-sapian pada bulan Muharram. Selametan pecel gerang merupakan kegiatan nyekar atau mengirim doa kepada leluhur masyarakat Desa Kenjo yang dilakukan di makam mbah Daeng setelah shalat ashar. Pecel gerang merupakan masakan yang terbuat dari campuran parutan kelapa yang disangrai dan gerang yang telah disangrai sebelumnya. Pecel gerang menjadi menu yang harus ada dalam prosesi ini sesuai dengan permintaan leluhurnya.

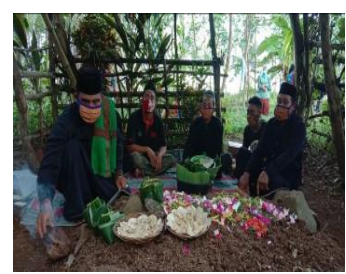

Gambar 8. Pelaksanaan Selametan Pecel Gerang
Pada tradisi selametan pecel gerang warga juga membuat makanan yang menyerupai hewan seperti kucing, cacing, ulat, cicak, sapi, keong, tikus, gajah, kambing, dan lain-lain, kecuali harimau. Menurut informasi warga $m b a h$ Daeng memelihara semua jenis binatang kecuali harimau sehingga bentuk harimau tidak dibuat dalam makanan tersebut. Makna dari pembuatan makanan menyerupai hewan adalah untuk nyelameti (mendoakan keselamatan) bukan hanya warga tetapi juga semua hewan.

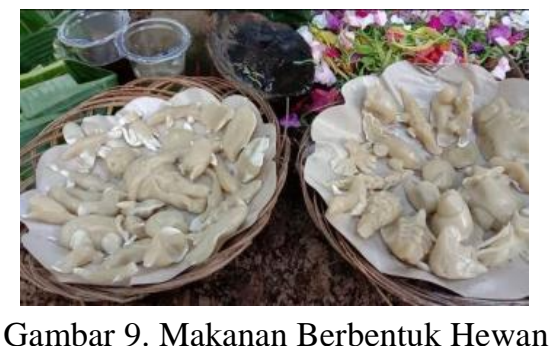

Prosesi kedua dinamakan tumpeng serakat, yaitu kegiatan makan bersama oleh seluruh masyarakat Desa Kenjo yang dilakukan di sepanjang jalan Desa Kenjo atau di depan pekarangan rumah warga. Tujuan dilaksanakan prosesi ini adalah selamatan agar serangkaian pelaksanaan tradisi sapi-sapian Desa Kenjo di keesokan harinya dapat berjalan dengan baik dan tidak ada kendala.
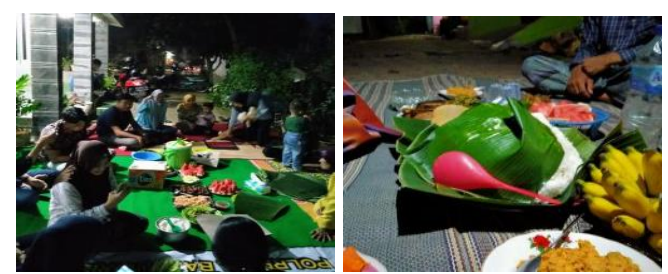

Gambar 10. Pelaksanaan Tumpeng Serakat 
Tidak ada ketentuan untuk bentuk dan ukuran tumpeng sehingga warga dapat membuat tumpeng secara umum atau sesuai dengan kemampuan masingmasing. Pembuatan tumpeng serakat, tidak harus dibuat warga secara perorangan atau tiap rumah tetapi dapat dibuat bersama-sama dengan saudara maupun tetangga.

Prosesi ketiga adalah ider bumi oncor-oncoran, yang dilaksanakan dengan tujuan menghilangkan berbagai penyakit atau tolak balak. Pelaksanaan prosesi ini dimulai setelah shalat isya'. Ider bumi oncor-oncoran dilakukan dengan mengelilingi desa membawa oncor (obor) dengan melantunkan shalawat Nabi di sepanjang jalan. Di setiap pertigaan atau perempatan, warga akan berhenti untuk melantunkan adzan kemudian menancapkan oncor. Selama prosesi ini berlangsung, listrik di seluruh wilayah Desa akan dipadamkan sementara.
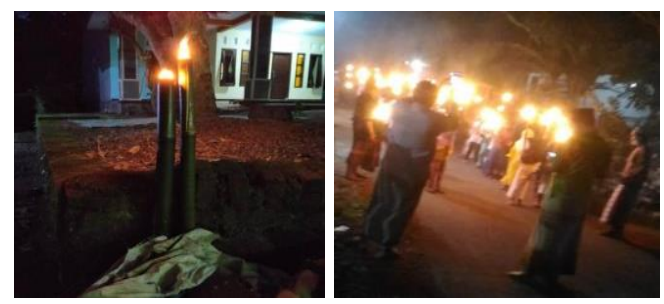

Gambar 11. Oncor (Kiri) dan Pelaksanaan Ider Bumi Oncor-Oncoran (Kanan)

Tradisi ider bumi oncor-oncoran dipersiapkan oleh kaum laki-laki di siang hari. Persiapan tersebut meliputi: mencari bambu, mengumpulkan serabut kelapa, dan solar. Selanjutnya bambu dipotong dengan panjang kurang lebih 2,5 sampai 3 ros. Bagian atas bambu disumbat dengan sepet (serabut) kelapa dan diberi minyak tanah sebagai bahan bakar. Karena saat ini minyak tanah cukup langka, maka bahan bakar tersebut diganti dengan solar.

Prosesi perayaan merupakan inti dari tradisi sapi-sapian Desa Kenjo yang dilakukan pada tanggal 1 Muharram. Prosesi perayaan dilakukan dengan kegiatan ngarak sapi-sapian dan atraksi sapi-sapian yang dilaksanakan di sawah. Acara ini diikuti oleh 3 dusun yang ada di Desa Kenjo yaitu Dusun Krajan, Dusun Talun, dan Dusun Salakan. Setiap dusun harus mempersembahkan sepasang sapi-sapian, dan syarat-syarat lain yang ada pada tradisi tersebut.

Salah satu hal menarik pada prosesi ini yaitu adanya dayang atau putri yang mengiringi sapi-sapian saat arak-arakan. Dayang diperankan oleh tujuh orang putri dari ketiga dusun dan telah memenuhi syarat untuk mengikuti tradisi ini, yaitu gadis dan tidak sedang menstruasi. Untuk mengantisipasi putri yang sedang menstruasi saat kegiatan, maka ketua adat menyarankan agar dayang diperankan oleh anak-anak yang belum pernah mengalami menstruasi. Untuk itu, dayang dapat diperankan oleh anak-anak berusia sekitar 5 sampai 11 tahun atau yang bersekolah di tingkat TK hingga SD. Dayang juga harus diperankan oleh putri yang sehat (tidak sedang sakit), karena peran dayang tidak boleh digantikan dari awal hingga akhir kegiatan.

Masing-masing dayang akan membawa rinjeng dan ireg yang berisi hasil panen baik polo pendem (tanaman yang buahnya terpendam di dalam tanah) maupun polo gumandul (buah yang menggantung pada suatu tumbuhan). 


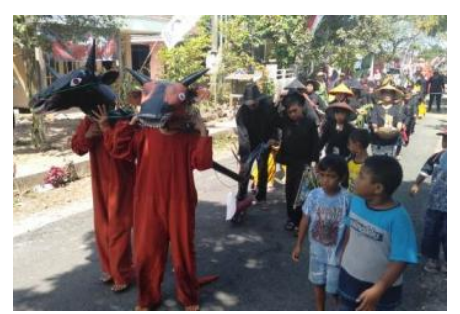

Gambar 12. Prosesi Perayaan dengan Mengarak Sapi-Sapian Diikuti Dayang di Belakang

Selanjutnya prosesi perayaan dilakukan di sawah. Warga memperagakan semua kegiatan menggarap sawah mulai dari membajak sawah, menabur benih padi, tandur pari (menanam padi), matun (mencabut rumput di sekitar tanaman padi), ngerujak (membuat rujak) saat pari meteng (padi akan mengeluarkan bulir/isi), dan gempung pari (panen padi).

Persiapan yang dilakukan sebelum prosesi tersebut adalah penyiapan lahan dengan membagi satu kedokan (petak) sawah menjadi empat bagian untuk masing-masing kegiatan. Pada bagian yang digunakan untuk kegiatan matun, tanaman padi disiapkan 2 bulan sebelumnya. Pada bagian kegiatan pari meteng, tanaman padi disiapkan 3 bulan sebelumnya. Sedangkan untuk kegiatan gempung pari, tanaman padi disiapkan 4 bulan sebelumnya.

Pada kegiatan membajak sawah, tiap sapi-sapian bergiliran memperagakan proses petani membajak sawah dengan menggunakan sapi. Tiap pasang sapi-sapian diberi waktu 10 menit untuk menyelesaikan kegiatan tersebut. Kemudian dilanjutkan dengan memperagakan kegiatan tandur pari yang hanya dilakukan oleh 3 atau 4 orang petani saja.
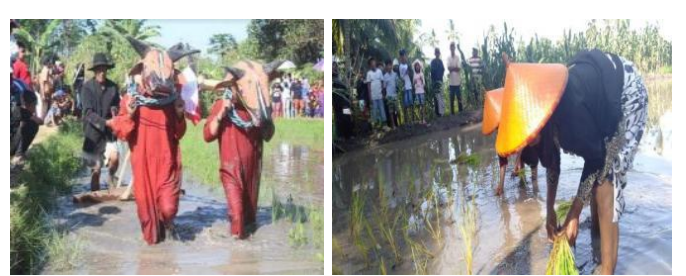

Gambar 13. Peragaan Membajak Sawah (Kiri) dan Tandur Pari (Kanan)

Pada kegiatan pari meteng warga akan melakukan tradisi rujakan, yaitu membuat rujak dari buah-buahan dengan bumbu yang terbuat dari cuka atau dikenal sebagai rujak kecut. Rujakan tersebut memiliki makna bahwa warga Desa Kenjo mengandaikan padi sebagai wanita hamil yang juga mengalami ngidam (keinginan untuk makan makanan berasa asam yang dirasakan wanita ketika awal masa kehamilan) sehingga perlu dibuatkan rujak kecut. Rujak dapat terlebih dahulu di rumah dengan diletakkan dalam takir (wadah terbuat dari daun pisang) atau dibuat di pinggir sawah dengan buah seadanya seperti jambu, pepaya, mangga muda, dan mentimun.
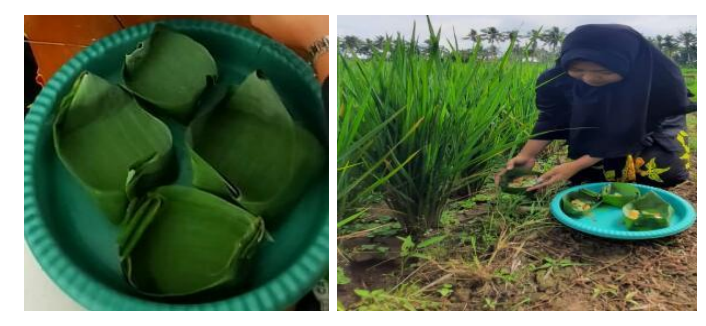

Gambar 14. Takir (Kiri) dan Prosesi Rujakan (Kanan)
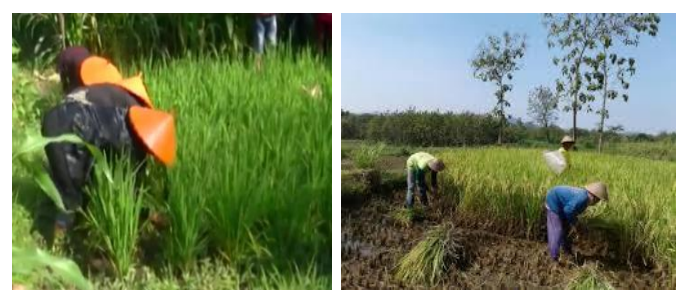

Gambar 15. Peragaan Matun (Kiri) dan Gempung Pari (Kanan) 


\section{Identifikasi Etnomatematika pada Tradisi Sapi-sapian}

Hasil eksplorasi pada tradisi sapisapian Desa Kenjo menunjukkan beragam matematika yang dapat dilihat secara kasat mata maupun perlu diperhatikan secara mendalam. Persiapan tradisi hingga pelaksanaan menunjukkan adanya peralatan yang dibuat atau sudah tersedia, seperti: kicer, seser, kepala sapi-sapian, rinjeng, ireg, cingkek, topi petani, oncor, dan sawah.

Pada kicer, rinjeng, ireg, dan bagian leher pada kepala sapi-sapian memuat konsep lingkaran (Gambar 16 dan 17).
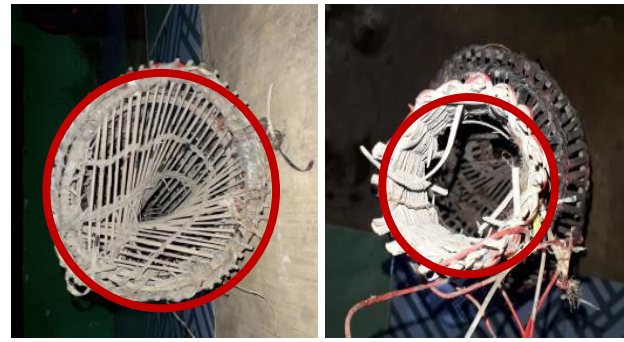

Gambar 16. Konsep Lingkaran pada Kicer (Bagian Atas dan Bawah)
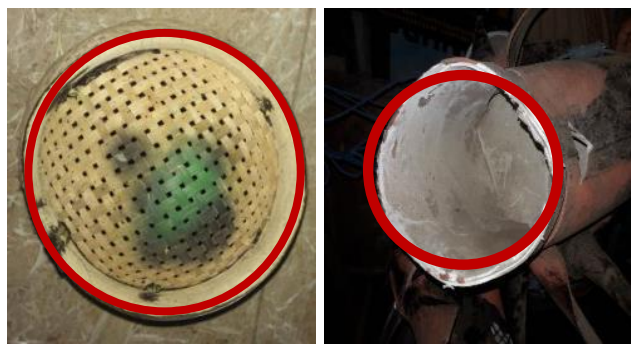

Gambar 17. Konsep Lingkaran pada Rinjeng/Ireg (Kiri) dan Leher pada Kepala SapiSapian

Konsep lingkaran tersebut sesuai dengan pendefinisan yang diberikan Dris \& Tasari (2011), yaitu lingkaran adalah kumpulan titik yang berjarak sama terhadap suatu titik tetap.

Pada cingkek (Gambar 18) dapat diidentifikasi konsep segitiga samakaki dan limas segitiga. Konsep tersebut sesuai dengan definisi segitiga sama kaki, yaitu segitiga yang dua dari tiga sisinya sama panjang (Hobri, dkk., 2018). Sedangkan konsep limas segitiga bersesuaian dengan bangun ruang yang tersusun atas sebuah alas berbentuk segitiga dengan sisi tegak berbentuk segitiga yang saling bertemu disatu titik atas (Syaifuddin, dkk., 2018).

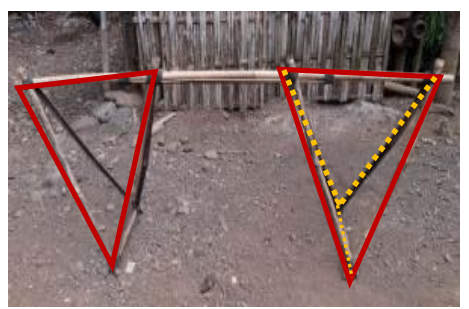

Gambar 18. Konsep Segitiga Samakaki dan Limas Segitiga pada Cingkek
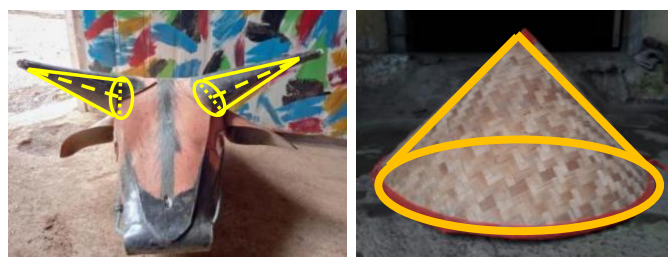

Gambar 19. Konsep Kerucut pada Kepada Sapisapian dan Topi Petani

Tanduk (Gambar 19) pada kepala sapi-sapian dan topi petani memuat konsep kerucut. Konsep tersebut sesuai dengan pen-definisian yang diberikan Syaifuddin, dkk. (2018), yaitu kerucut adalah bangun ruang sisi lengkung yang tersusun dari alas berbentuk lingkaran dan diselubungi oleh segitiga.
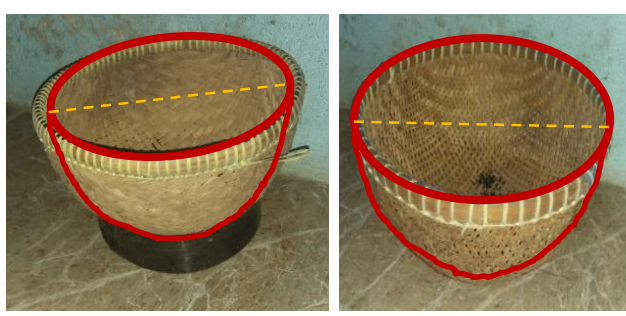

Gambar 20. Konsep Setengah Lingkaran pada Rinjeng dan Ireg 
Rinjeng dan ireg (Gambar 20) juga memuat konsep setengah lingkaran. Syaifuddin, dkk. (2018) menyebutkan bahwa bola merupakan bangun ruang sisi lengkung yang dibatasi oleh satu bidang lengkung dan didapat dari bangun setengah lingkaran yang diputar satu putaran penuh atau $360^{\circ}$ (derajat) pada garis tengahnya.

Oncor (Gambar 21) memuat konsep satuan tidak baku dan konsep tabung. Panjang oncor ditentukan 2,5 sampai 3 ros dapat dikonversikan dengan satuan baku sebesar $\pm 1-1,5$ meter. Konsep tersebut diidentifikasi sesuai dengan pengertian tabung, yaitu bangun ruang sisi lengkung yang memiliki 3 sisi terdiri dari tutup dan alas berbentuk lingkaran berukuran sama dan sisinya dilingkari oleh persegi panjang (Syaifuddin, dkk., 2018:111).

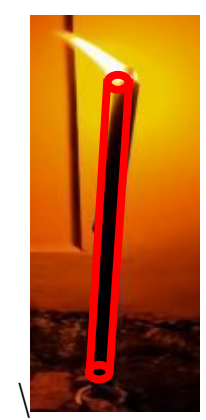

Gambar 21. Konsep Tabung pada Oncor

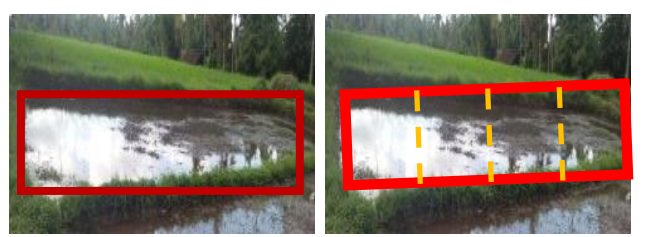

Gambar 22. Konsep Persegi Panjang (Kiri) dan Konsep Pecahan (Kanan) pada Sawah Sekedok

Sawah dengan ukuran sekedok memuat konsep persegi panjang dan satuan tidak baku. Ukuran sawah sekedok (sepetak) merupakan ukuran yang dipahami oleh masyarakat Desa kenjo, yang jika dikonversikan dengan satuan baku menunjukkan ukuran $\pm 50 \mathrm{x}$ 30 meter (Gambar 22). Sedangkan pembagian dari sawah tersebut memuat konsep pecahan.

Konsep persegipanjang dapat diidentifikasi sesuai dengan pendapat Hobri, dkk. (2018), yaitu bangun datar yang memiliki dua pasang sisi berhadapan sama panjang dan empat buah titik sudut siku-siku. Hobri, dkk. (2018) juga mendefinisikan konsep pecahan sebagai bilangan yang dinyatakan sebagai $\frac{a}{b}$ dengan a dan $b$ adalah bilangan bulat dan $b$ tidak sama dengan nol $(b \neq 0)$ atau a disebut pembilang dan $b$ disebut penyebut.

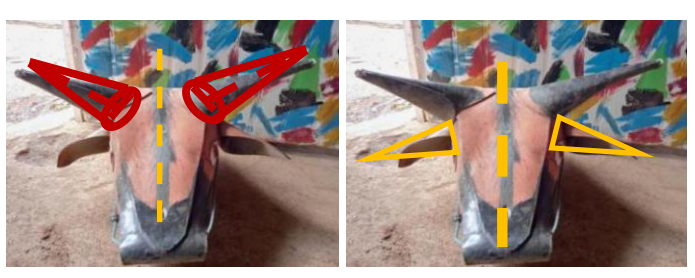

Gambar 23. Konsep Refleksi/Pencerminan pada Tanduk (Kiri) dan Telinga (Kanan) Kepala Sapi-Sapian

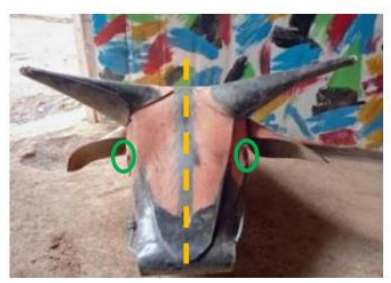

Gambar 24. Konsep Refleksi/Pencerminan pada Mata Kepala Sapi-Sapian

Kepala sapi-sapian (Gambar 23 dan 24) memuat konsep transformasi geometri yaitu refleksi/pencerminan pada bagian tanduk, mata dan telinga. Konsep tersebut diidentifikasi sesuai dengan pengertian refleksi atau pencerminan, yaitu transformasi geometri 
berupa pergeseran atau pemindahan semua titik pada bidang geometri kearah sebuah garis atau cermin dengan jarak sama dengan dua kali jarak titik ke cermin.

Pada proses pembuatan kepala sapi-sapian digunakan satuan tidak baku sebagai alat pengukurnya, di antaranya: jarak satu jengkal dari tangan orang dewasa yang dapat dikonversikan ke satuan baku dengan ukuran antara \pm 21 $22 \mathrm{~cm}$; jarak antara tanduk dan mata sapi sebesar 3 jari orang dewasa yang dapat dikonversikan ke satuan baku dengan ukuran sekitar 3-4 cm; jarak antara telinga dengan tanduk sebesar 1 jari telunjuk orang dewasa yang dapat dikonversikan ke satuan baku sekitar 1-2 $\mathrm{cm}$. Konsep satuan baku dapat dipahami sebagai satuan yang telah ditetapkan secara internasional yang disebut dengan satuan sistem internasional.

Berbagai pembahasan di atas menunjukkan bahwa dalam tradisi budaya memuat etnomatematika sesuai dengan hasil penelitian sebelumnya di antaranya tentang: masyarakat suku Madura di Situbondo yang melakukan aktivitas matematika dalam kegiatan jual beli (Khairadiningsih, Hobri, \& Dian, 2015); aktivitas matematika pada festival budaya di Yogyakarta seperti transformasi geometri, luas permukaan kerucut, jaring-jaring kerucut, teorema Pythagoras, dan keliling lingkaran (Maryati \& Prahmana, 2018); serta aktivitas matematika dalam budaya Sunda seperti memperkirakan, mengukur, dan membuat pola (Muhtadi, dkk., 2017).

\section{PENUTUP}

Tradisi sapi-sapian memuat 4 prosesi utama yaitu selametan pecel gerang, tumpeng serakat, ider bumi oncor-oncoran, dan perayaan. Pada proses persiapan dan tiap-tiap prosesi memuat konsep-konsep matematika seperti: (1) konsep geometri dua dimensi yaitu: persegi panjang, lingkaran, dan segitiga sama kaki; (2) konsep geometri tiga dimensi yaitu: kerucut, limas segitiga, setengah bola, dan tabung; (3) konsep pecahan; (4) konsep transformasi geometri yaitu: refleksi/pencerminan; dan (5) konsep pengukuran tradisional dengan satuan tidak baku. Kondisi budaya yang dekat dengan kehidupan siswa diharapkan dapat menjadi basis pengembangan pembelajaran matematika. Sehingga siswa lebih mudah mempelajari matematika melalui budaya yang dikenalnya.

\section{DAFTAR PUSTAKA}

Abi, A. M. (2016). Integrasi Etnomatematika Dalam Kurikulum Matematika Sekolah. JPMI (Jurnal Pendidikan Matematika Indonesia), Vol. 1 No. $1,1-6$.

Aini, Z., Afifah, N., Muslim, I., \& Hasanah, S. I. (2019). Eksplorasi Etnomatematika Budaya Karabhen Sape Madura. Journal of Medives: Journal of Mathematics Education IKIP Veteran Semarang, Vol. 3, No. 2 , 177-183.

Cahyani, I. A., Setiawan, T. B., \& yudianto, E. (2018). Kekongruenan dan Kesebangunan pada Perangkat Upacara Adat Kebo-koboan Alasmalang. Kadikma, Vol. 9, No. 3 , 139-147. 
Cimen, O. A. (2014). Discussing ethnomathematics: Is mathematics culturally dependent? Procedia Social and Behavioral Sciences $152,523-528$.

D'Ambrosio,

$\mathrm{U}$.

(2001).

Ethnomathematics, Link between

Traditions and Modernity.

Rotterdam, The Netherlands:

Sense Publisher.

Darwis, R. (2017). Tradisi Ngaruwat Bumi dalam Kehidupan Masyarakat (Studi Deskriptif Kampung Cihideung Girang Desa Sukakerti Kecamatan Cisalak Kabupaten Subang). Jurnal Studi Agama-agama dan Lintas Budaya, Vol. 2, No. 1 , 75-83.

Dris, J., \& Tasari. (2011). Matematika 2, Untuk SMP dan MTs Kelas VIII. Jakarta: Pusat Kurikulum dan Perbukuan, Kementerian Pendidikan Nasional.

Hidayatulloh, N., \& Hariastuti, R. M. (2018). Kajian Etnomatematika Angklung Paglak Banyuwangi. AKSIOMA Jurnal Pendidikan Matematik, Vol. 7, No. 3 , 380-389.

Himmah, F., Setiawan, T. B., Monalisa, L. A., Pambudi, D. S., \& Trapsilasiwi, D. (2019). Ethnomathematics of Tumpeng and Banyuwangi Tumpeng Sewu. Pancaran Pendidikan, Vol. 8, No. $1,73-84$.

Hobri, Susanto, Syaifuddin, M., Maylistiyana, D. E., Hosnan, Cahyanti, A. E., et al. (2018). Senang Belajar Matematika MI/SD Kelas IV. Jakarta: Pusak Kurikulum dan Perbukuan, Balitbang, Kemendikbud.

Khairadiningsih, R. N., Hobri, \& Dian. (2015). Eksplorasi Etnomatematika Masyarakat Suku
Madura di Situbondo. Artikel Ilmiah Mahasiswa, Vol. 2, No. 1 , 1-4.

Maryati, \& Prahmana, R. C. (2018). Ethnomathematics: Exploring the activities of culture festival. The Sixth Seminar Nasional Pendidikan Matematika Universitas Ahmad Dahlan 2018 (hal. 1-6). Yogyakarta: Universitas Ahmad Dahlan.

Muhtadi, D., Sukirwan, Warsito, \& Prahmana, R. C. (2017). Sundanese Ethnomathematics: Mathematical Activities in Estimating, Measuring, and Making Patterns. Journal on Mathematics Education, Vol. 8, No. 2 , 185-198.

Syaifuddin, M., Susanto, Hobri, Maylistiyana, D. E., Hosnan, Cahyanti, A. E., et al. (2018). Senang Belajar Matematika. Jakarta: Pusat Kurikulum dan Perbukuan, Balitbang, Kemendikbud.

Tandililing, E. (2013). Pengembangan Pembelajaran Matematika Sekolah dengan Pendekatan Etnomatematika Berbasis Budaya Lokal sebagai Upaya untuk Meningkatkan Kualitas Pembelajaran Matematika di Sekolah. Seminar Nasional Matematika dan Pendidikan Matematika (hal. MP 193 -MP 202). Yogyakarta: Jurusan Pendidikan Matematika FMIPA UNY. 